\title{
PENGARUH VISUAL MERCHANDISING DAN PRODUCT ASSORTMENT TERHADAP IMPULSE BUYING (Survei Pada Konsumen Rabbani Kota Sukabumi)
}

\author{
Nuri Firdayanti ${ }^{1}$ \\ Asep Muhamad Ramdan ${ }^{2}$ \\ Erry Sunarya ${ }^{3}$
}
Fakultas Ilmu Administrasi dan Humaniora Universitas Muhammadiyah Sukabumi, Jawa Barat, Indonesia ${ }^{1,2,3}$
Email: nurifirdayanti088@ummi.ac.id ${ }^{1}$,amr37ramdan@ummi.ac.id ${ }^{2}$, errysoen@ummi.ac.id ${ }^{3}$

\begin{abstract}
This study aims to study the effect of visual merchandising and product assortment on impulse buying. The data analysis technique used is a double linear regression analysis with sample techniques using non-probability sampling samples by incidental sampling method. Data collection by spreading questionnaire to 150 respondents. Data processing using IBM SPSS software version 24. Results showed that simultaneously visual merchandising and product assortment effect positive and significant to impulse buying. A partial test shows the visual merchandising effect positively and significantly on impulse buying. While the product assortment influential but not significant to impulse buying.
\end{abstract}

Keywords: visual merchandising; product assortment; impulse buying; fashion.

\begin{abstract}
ABSTRAK
Penelitian ini bertujuan untuk mengetahui pengaruh visual merchandising dan product assortment terhadap impulse buying. Teknik analisa data yang digunakan yaitu analisis regresi linear berganda dengan teknik sampel menggunakan sampel non-probability sampling dengan metode incidental sampling. Pengumpulan data dengan cara penyebaran kuesioner kepada 150 responden. Pengolahan data menggunakan software IBM SPSS versi 24. Hasil menunjukan bahwa secara simultan visual merchandising dan product assortment berpengaruh positif dan signifikan terhadap impulse buying. Uji parsial menunjukan visual merchandising berpengaruh positif dan signifikan terhadap impulse buying. Sedangkan product assortment berpengaruh namun tidak signifikan terhadap impulse buying.
\end{abstract}

Kata Kunci: visual merchandiisng; product assortment; impulse buying; fashion. 


\section{PENDAHULUAN}

Perkembangan industri fashion sekarang ini dapat berkontribusi sekitar $18,01 \%$ atau Rp 116 triliun. Sekarang ini banyak trend fashion yang berkembang diantaranya merupakan pakaian ready to wear atau pakaian jadi dan banyak mengusung bisnis fast fashion juga memiliki pergantian mode dengan cepat juga biaya produksi yang sangat rendah (Cnbc, 2019).

Industri fashion juga mampu memberikan kontribusi Rp 181,6 milyar untuk Gross Domestic Product (GDP) dan jumlahnya adalah penyumbang terbesar kedua setelah ekonomi kreatif kuliner sektor, karena itu industri fashion akan memicu pasar untuk terus berkembang (Novia, 2015). Dengan itu maka banyaknya peluang bagi industri fashion juga dengan banyak munculnya industri fashion menyebabkan terjadinya persaingan. Oleh karena itu perusahaan harus kreatif dan inovatif dalam pengembangan produknya agar tetap bisa bersaing ditengah banyak munculnya perusahaan fashion di Indonesia.

Salah satu trend fashion yang kini sedang berkembang yaitu trend fashion muslim yang kini semakin meningkat. Meningkatnya fashion muslim di Indonesia telah mendorong industri fashion muslim domestik. Dengan meningkatnya wanita yang menggunakan hijab secara tidak langsung menguntungkan industri fashion saat ini. Dalam waktu yang singkat, pakaian muslim menjadi segmen yang penting bagi industri tekstil nasional (Kompasiana, 2019).

Berdasarkan data kementrian perdagangan produk pakaian muslim yang dijual untuk pasar domestik sekitar $80 \%$, dan $20 \%$ sisanya di ekspor. Selanjutnya pada tahun 2015 ekspor pakaian muslim mencapai angka Rp 58,5 triliun. 
Sepanjang tahun 2013, berdasarkan Badan Pusat Statistik (BPS) sekitar 1.107.955 unit perusahaan yang bergerak pada bidang fashion. Diantaranya 10\% perusahaan besar, $20 \%$ perusahaan menengah hingga $70 \%$ sisanya adalah perusahaan kecil (Kumparan, 2019).

Dengan meningkatnya trend fashion muslim saat ini maka pasar mengalami persaingan yang sangat ketat. Khususnya perusahaan atau toko-toko ritel ofline yang mana sekarang ini harus bisa mempertahankan diri ditengah munculnya banyak pesaing. Seperti banyaknya store, toko-toko maupun outlet yang menawarkan produk serupa. Perusahaan harus bisa menciptakan strategi yang tepat untuk dapat bertahan ditengah persaingan dan tentu tujuannya untuk dapat menarik konsumen. Salah satu cara yaitu dengan menciptakan visual merchandising toko semenarik mungkin dan menyediakan produk yang beragam untuk menciptakan pembelian impulsif konsumen (impulse buying).

Dalam melakukan pembelian konsumen bisa sama maupun berbeda. Ada pembelian yang sudah direncanakan, ada juga pembelian yang belum direncanakan. Perilaku konsumen yang belum merencanakan pembelian dapat mendorong adanya perilaku pembelian spontan (impulse buying) (Sunyoto, 2014). Pembelian impulsif dapat terjadi akibat adanya pengaruh lingkungan sekitar dan juga dari dalam diri seseorang (Mulianingsih et al., 2019). Pembelian impulsif juga mengacu pada pembelian atau akuisi barang secara impulsif dari pada perencanaan terlebih dahulu (Choudhary, 2014).

Bisnis fashion saat ini memiliki kejeniusan dalam hal visual merchandising yang tujuannya bagaimana agar orang tertarik untuk masuk kedalam toko. (Ahmed 
\& Parmar, 2013) menyatakan, tampilan produk pada suatu toko yang menarik akan mengarah pada perilaku pembelian impulsif konsumen.

Visual merchandising dapat menjadi faktor pendorong impulse buying (Novia, 2015). Visual merchandising juga berkaitan dengan perilaku pembelian impulsif konsumen (Kaur \& Jain, 2016). Visual merchandising membantu menarik perhatian konsumen dengan cara memberikan kesan yang berbeda dengan cara membuat interior yang menarik, suasana yang nyaman, pencahayaan yang baik sehingga konsumen akan cenderung tertarik dan melakukan pembelian impulsif (Sumeisey, 2014). Penelitian terdahulu mengenai visual merchandising, dimana peneliti terdahulu (Muthiah et al., 2018; Novia, 2015; Pancaningrum, 2017) menyatakan visual merchandising memiliki pengaruh terhadap pembelian impulsif (impulse buying).

Selain itu, keberagaman produk (product assortment) juga harus diperhatikan. Produk beragam yang baik itu tidak hanya dapat menarik minat beli konsumen melainkan dapat membuat konsumen untuk melakukan pembelian (Foster, 2015). Hal ini sejalan dengan peneliti terdahulu yang menyatakan bahwa dengan menyediakan produk yang beragam dapat memberikan pengaruh terhadap keputusan pembelian impulsif konsumen (Anggraeni et al., 2016).

Rabbani merupakan salah satu toko fashion muslim yang ikut serta dalam meramaikan bisnis fashion di Indonesia. Rabbani merupakan perusahaan ritel busana muslim yang merupakan profesor kerudung pertama dan terbesar di Indonesia. Produk yang dikeluarkan Rabbani berupa kerudung instan dan kini banyak produk lainnya yang sudah dikembangkan diantaranya yaitu busana 
muslim. Rabbani kini telah memiliki beberapa cabang di Indonesia, salah satunya yaitu Store Rabbani di Kota Sukabumi yang akan menjadi objek dalam penelitian ini.

Rabbani tentunya bukan satu-satunya toko fashion yang menjual busana muslim di Kota Sukabumi. Selain Rabbani, di Kota Sukabumi juga terdapat banyak outlet pesaing yang menjual produk sejenis seprti Zoya, Elzatta, Dauky dan lainlain. Dengan persaingan yang semakin tinggi membuat para pelaku usaha berlomba-lomba untuk menjadi pangsa pasar (marker share). Berdasarkan hasil riset Top Brand Busana Muslim dapat dilihat pada Tabel 1.

Tabel 1.

\section{Top Brand Index Busana Muslim}

\begin{tabular}{ccllll}
\hline No & Merek & \multicolumn{1}{c}{2016} & \multicolumn{1}{c}{2017} & \multicolumn{1}{c}{2018} & \multicolumn{1}{c}{2019} \\
\hline 1. & Rabbani & $17.9 \%$ & $16.0 \%$ & $22.2 \%$ & $17.8 \%$ \\
2. & Elzatta & $7.1 \%$ & $5.4 \%$ & - & - \\
3. & Zoya & $25.3 \%$ & $10.2 \%$ & $15.4 \%$ & $13.0 \%$ \\
4. & Almadani & - & $3.4 \%$ & $9.4 \%$ & $15.8 \%$ \\
5. & Azka & - & - & $9.3 \%$ & $9.4 \%$ \\
\hline
\end{tabular}

Sumber : Top Brand Award Busana Muslim, 2019

Dari data pada Tabel 1 terlihat bahwa Top Brand Index pada produk Rabbani mengalami naik turun dari tahun 2016 hingga 2019, Rabbani sebenarnya top brand namun bisa dilihat dimana pada dua tahun terakhir Rabbani mengalami penurunan yang cukup pesat dibandingkan dengan produk pesaing yaitu pada tahun 2018 sebesar $22.2 \%$ dan pada tahun 2019 mengalami penurunan menjadi $17.8 \%$. Oleh sebab itu, produk Rabbani harus tetap mempertahankan eksistensinya serta meningkatkan kembali penjualannya, salah satunya yaitu dengan melakukan visual merchandising yang baik dan menyediakan berbagai macam produk yang beragam yang bisa menarik konsumen dalam melakukan pembelian. 
Visual merchandising adalah sebuah teknik dalam mempresentasikan barang dagangan yang ditunjukan pada pelanggan yang potensial (Jain et al., 2012). Visual merchandising juga sebagai penyajian barang dagangan melalui tampilan, acara khusus, koordinasi mode dan departemen merchandising yang akan dijual berupa barang atau jasa oleh suatu perusahaan (Kaur \& Jain, 2016).

Mehta dan Chugan dalam (Sudarsono, 2017) menyatakan bahwa terdapat beberapa dimensi dari visual merchandising diantaranya : 1) Window display, 2) In-store form/mannequin display, 3) Floor merchandising, 4) Promotional signage. Lain halnya dengan dimensi yang dikemukakan oleh Krishnakumar dalam (Amalia, 2016) yaitu 1) Store Layout, 2) store design, 3) item display, 4) promotional signage, 5) window display.

Maka penelitian ini menggunakan empat dimensi visual merchandising yaitu: 1) window display (Amalia, 2016; Sudarsono, 2017), 2) in-store form/mannequin display (Sudarsono, 2017), 3) floor merchandising (Sudarsono, 2017), dan 4) promotional signage (Amalia, 2016; Sudarsono, 2017).

Peneliti terdahulu (Pancaningrum, 2017) menyatakan bahwa "semakin baik visual merchandise maka akan semakin meningkatkan pembelian impulsif seseorang". Sehingga dapat disimpulkan bahwa visual merchandising berpengaruh positif dan signifikan terhadap impulse buying (Muthiah et al., 2018; Novia, 2015). $\mathbf{H}_{1}=$ visual merchandising berpengaruh positif dan signifikan terhadap impulse buying.

Keragaman produk atau product assortment merupakan kumpulan dari seluruh lini produk yang didalamnya merupakan jumlah lini produk, pilihan ukuran 
produk, pilihan warna produk yang ditawarkan penjual kepada pembeli (Foster, 2015). Adapun (Kotler \& Keller, 2016) juga mengemukakan bahwa "bauran produk atau sering disebut juga product assortment adalah serangkaian produk dan barang yang ditawarkan perusahaan untuk dijual".

Menurut (Kotler \& Keller, 2016) terdapat empat dimensi keragaman produk (product assortment) yaitu : 1) Width , 2) Length, 3) Depth, dan 4). Consistency. Maka peneliti menggunakan indikator product assortment menurut (Kotler \& Keller, 2016) pada penelitian ini yaitu: 1) banyaknya lini produk yang berbeda, 2) tingkat variasi jenis produk yang berbeda, 3) banyaknya jenis dalam satu lini produk, 4) konsistensi ketersediaan produk yang dijual.

Penelitian terdahulu mengenai keragaman produk yang dilakukan oleh (Anggraeni et al., 2016) mengemukakan bahwa dengan menyediakan produk yang beragam dapat memberikan pengaruh positif dan signifikan terhadap keputusan pembelian impulsif. Hasil penelitian menunjukan bahwa keragaman produk berpengaruh positif dan signifikan terhadap impulse buying. Sejalan dengan hasil penelitian (Foster, 2015) yang menyatakan bahwa product assortment berpengaruh terhadap impulse buying.

$\mathbf{H}_{2}=$ product assortment berpengaruh positif dan signifikan terhadap impulse buying.

Impulse buying merupakan pembelian yang mendadak secara langsung tanpa adanya niat belanja sebelumnya (Thomas et al., 2018). Pembelian impulsif juga sebagai reaksi terhadap adanya pemicu eksternal seperti melihat produk yang diinginkan di suatu toko (Choudhary, 2014). 
Menurut Sugiharto dan Japrianto dalam (Indarsih et al., 2019) terdapat dimensi untuk mengukur pembelian impulsif yaitu: Spontanitas Pembelian, 2) Kekuatan pembelian, 3) Kegairahan dan Stimulasi dan 4) Ketidakpedulian akan akibat.

Maka peneliti menggunakan indikator impulse buying menurut Sugiharto dan Japrianto dalam (Indarsih et al., 2019) pada penelitian ini yaitu : 1) Kecenderungan konsumen membeli tanpa rencana. 2) kemampuan konsumen dalam mengendalikan diri. 3) dorongan yang kuat untuk segera membeli. 4) kepedulian akibat yang akan terjadi setelah melakukan pembelian.

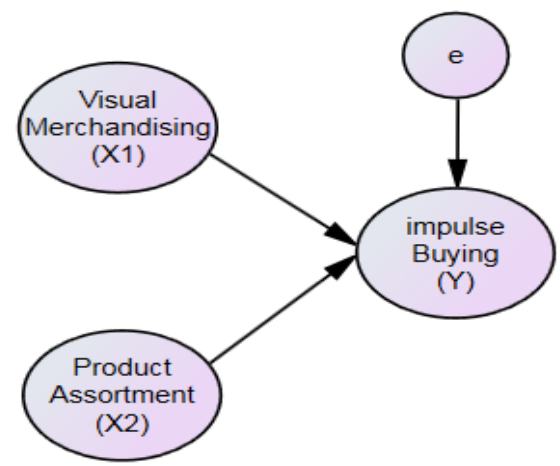

Gambar 1.

Model Penelitian

\section{METODE PENELITIAN}

Penelitian ini dilakukan di Store Rabbani yang merupakan toko fashion busana muslim di Kota Sukabumi. Menggunakan metode kuantitatif dengan pendekatan asosiatif, pengolahan data menggunakan software IBM SPSS 24. Teknik penelitian yang digunakan yaitu non-probability sampling dengan pengambilan sampel menggunakan metode incidental sampling dimana teknik 
penarikan sampel berdasarkan kebetulan. Jumlah sampel sebanyak 150 responden dengan cara menyebarkan kuesioner kepada konsumen Rabbani.

Kuesioner yang diberikan memiliki kriteria serta bobot nilai berdasarkan skala interval dimana dengan melakukan rangking 1 sampai 5 dengan menggunakan skala perbedaan sematik (differencial sematic scale).

\section{HASIL DAN PEMBAHASAN}

Uji kelayakan model sebagai cara untuk mengetahui model yang digunakan itu layak digunakan atau tidak. Adapun hasil olah data ditunjukan pada Tabel 2.

Tabel 2.

Hasil Uji F

\begin{tabular}{|c|c|c|c|c|c|c|}
\hline \multicolumn{7}{|c|}{ ANOVA $^{a}$} \\
\hline \multirow{2}{*}{\multicolumn{2}{|c|}{ Model }} & Sum Of & & & & \\
\hline & & Squares & df & Mean Square & $\mathbf{F}$ & Sig. \\
\hline \multirow[t]{3}{*}{1} & Regression & 354,877 & 2 & 177,438 & 18,915 &, $000^{\mathrm{b}}$ \\
\hline & Residual & 1378,963 & 147 & 9,381 & & \\
\hline & Total & 1733,840 & 149 & & & \\
\hline
\end{tabular}

a. Dependent Variable: Impulse Buying

b. Predictors: (Constant), Product Assortment, Visual Merchandising

Sumber: Data diolah, 2020

Hasil uji $\mathrm{F}$ yaitu nilai $\mathrm{F}_{\text {hitung }}$ 18,915 > 3,06 menunjukan bahwa $\mathrm{F}_{\text {hitung }}$ lebih besar dari $F_{\text {tabel. }}$ Serta nilai regresi memiliki tingkat signifikan $0,000<0,05$. Maka dapat disimpulkan bahwa adanya pengaruh antara variabel visual merchandising dan product assortment terhadap impulse buying secara simultan dapat diterima. 
Tabel 3.

Hasil Koefisien Determinasi

\begin{tabular}{lcccc}
\hline \multicolumn{5}{c}{ Model Summary } \\
\hline Model & $\mathbf{R}$ & R Square & $\begin{array}{c}\text { Adjusted R } \\
\text { Square }\end{array}$ & $\begin{array}{c}\text { Std. Error of } \\
\text { the Estimate }\end{array}$ \\
\hline 1 &, $452^{\text {a }}$ &, 205 &, 194 & 3,063 \\
\hline a. & Predictors: (Constant), Product Assortment, Visual Merchandising & \\
b. & Dependent Variable: Impulse Buying & & \\
\hline \multicolumn{3}{l}{ Sumber: Data diolah, 2020 }
\end{tabular}

Sumber: Data diolah, 2020

Hasil menunjukan bahwa besar nilai korelasi (R) yaitu 0,452 dan diperoleh koefisien determinasi ( $\mathrm{R}$ Square) sebesar 0,205 yang artinya pengaruh variabel visual merchandising dan product assortment terhadap impulse buying sebesar 20,5\% serta sisanya 79,5\% dipengaruhi oleh variabel lain yang tidak diteliti.

Kemudian dilakukan analisis regresi linear berganda dengan tujuan untuk mengetahui apakah variabel independen berpengaruh terhadap variabel dependen. Selanjutnya untuk menguji hipotesis yang diajukan, dilakukan uji t hasil dari pengolahan data menggunakan alat bantu SPSS. Uji t sebagai cara dalam menentukan hipotesis antar variabel satu dengan yang lain apakah memiliki tingkat signifikan yang sama atau tidak (Lupiyoadi \& Ikhsan, 2015). Adapun hasil pengolahan data yaitu:

Tabel 4.

Hasil Regresi Linear Berganda \& Uji T

\begin{tabular}{|c|c|c|c|c|}
\hline \multicolumn{5}{|c|}{ Visual Merchandising (X1) } \\
\hline & Coeff & SE & $\mathbf{T}$ & P-Value \\
\hline Constant & 4,847 & 1,495 & 3,243 & 0,001 \\
\hline Visual Merchandising (X1) & 0,412 & 0,124 & 3,311 & 0,001 \\
\hline \multicolumn{5}{|c|}{ Product Assortment (X2) } \\
\hline & Coeff & SE & $\mathbf{T}$ & P-Value \\
\hline Constant & 4,847 & 1,495 & 3,243 & 0,001 \\
\hline Product Assortment (X2) & 0,130 & 0,115 & 1,128 & 0,261 \\
\hline
\end{tabular}


Hasil menunjukan nilai constant (a) sebesar 4.847 dengan nilai visual merchandising sebesar 0,412 dan nilai product assortment sebesar 0,130 . Hal ini menunjukan adanya pengaruh positif sehingga persamaan regresi nya adalah :

$\mathrm{Y}=\beta_{1} \mathrm{X}_{1}+\beta_{2} \mathrm{X}_{2}$

Maka

$\mathrm{Y}=0,412 \mathrm{X}_{1}+0,130 \mathrm{X}_{2}$

Berdasarkan hasil hipotesis pertama menunjukan nilai signifikan sebesar $0,001<0,05$ dan nilai $\mathrm{T}_{\text {hitung }} 3,311>1.976$. Sehingga dapat disimpukan bahwa terdapat pengaruh positif dan signifikan antara visual merchandising terhadap impulse buying. Hal tersebut sejalan dengan hasil penelitian (Muthiah et al., 2018; Novia, 2015). Maka dengan itu, semakin baik visual merchandising maka akan semakin meningkatkan pembelian impulsif seseorang (Pancaningrum, 2017).

Adapun hasil hipotesis yang kedua menunjukan bahwa product assortment berpengaruh namun tidak signifikan terhadap impulse buying hal ini dibuktikan dengan nilai signifikansi yang lebih besar yakni 0,261 >0,05 dan nilai $\mathrm{T}_{\text {hitung }} 1,128$ $<$ 1.976. Sehingga penelitian ini berbeda dengan hasil penelitian (Anggraeni et al., 2016) yang mengemukakan bahwa dengan menyediakan produk yang beragam dapat memberikan pengaruh positif dan signifikan terhadap pembelian impulsif. Namun senada dengan hasil penelitian (Foster, 2015) yang menyatakan bahwa product assortment berpengaruh terhadap impulse buying. 


\section{SIMPULAN DAN SARAN}

Berdasarkan penelitian diatas, dapat disimpulkan bahwa secara simultan terdapat pengaruh positif dan signifikan antara variabel independen terhadap variabel dependen. Selanjutnya untuk uji hipotesis secara parsial menunjukan bahwa visual merchandising $\left(\mathrm{X}_{1}\right)$ mempunyai pengaruh positif dan signifikan terhadap impulse buying. Kemudian product assortment $\left(\mathrm{X}_{2}\right)$ mempunyai pengaruh namun tidak signifikan terhadap impulse buying.

Adapun beberapa saran yang ditunjukan untuk Rabbani Kota Sukabumi dalam menciptakan pembelian impulsif konsumen. Yang pertama, visual merchandising dapat menjadi salah satu faktor penyebab terjadinya impulse buying sehingga penting bagi Rabbani untuk memperhatikan tampilan barang dagangan yang ada pada window display dengan semenarik mungkin yang akan menjadi daya tarik sendiri bagi konsumen untuk memasuki toko atau tidak. Kedua, Rabbani juga harus konsisten didalam menyediakan produk yang selalu tersedia di toko sebagai salah satu bentuk dalam menciptakan pembelian impulsif konsumen.

\section{REFERENSI}

Ahmed, R. R., \& Parmar, V. (2013). Factors influencing impulse buying behavior. European Journal of Scientific Research, 100(3), 67-79.

Amalia, S. (2016). Analisis Pengaruh Hedonic Consumption Tendency, Fashion Involvement dan Visual Merchandising terhadap Consumer Buying Decision Process pada Zoya Fashion. Universitas Islam Negeri Syarif Hidayatullah Jakarta.

Anggraeni, J., Paramita, patricia dhiana, \& Warso, m mukery. (2016). Pengaruh Keanekaragaman Produk, Kualitas Pelayanan dan Store Atmosphere terhadap Impulse Buying di Butik Cassanova Semarang. Journal of Management, 2(2). 
Choudhary, S. (2014). Study of Impulse Buying Behavior of Consumers. International Journal of Advance Research in Computer Science and Management Studies, 2(9), 1-4.

Cnbc. (2019). Gairah Industri Fashion Indonesia. CNBC Indonesia. https://www.cnbcindonesia.com/lifestyle/20190712155341-35-84555/gairahindustri-fashion-indonesia

Foster, B. (2015). Imfluence Of Product Assortment and Hedonic Lifestyle on Impulse Buying Customer Of Trans Studio Mall (TSM). 17(1), 56-59.

Indarsih, P., Sudodo, Y., \& Nuryani, H. S. (2019). Pengaruh Harga Dan Kualitas Informasi Terhadap Pembelian Impulsif Secara Online (Studi Kasus pada Mahasiswa Fakultas Ekonomi dan Bisnis Universitas Teknologi Sumbawa). 2(1).

Jain, V., Sharma, A., \& Narwal, P. (2012). Impact of Visual Merchandising on Consumer Behaviour towards Women's Apparel. International Journal of Research in Management Issue 2, 5(2). http://www.rspublication.com/ijrm/ijrm_index.htm

Kaur, A., \& Jain, R. (2016). The Impact Of Visual Merchandising On Impulse Buying Behaviour In Organised Retail Stores. International Journal of Engineering, Management \& Medical Research (IJEMMR), 2(4).

Kompasiana. (2019). volume penjualan busana muslim di indonesia. Kompasiana beyond Blogging. https://www.kompasiana.com/klikpintar31/5c74f720677ffb47c5242267/volu me-penjualan-busana-muslim-di-indonesia?page $=$ all

Kotler, P., \& Keller, kevin lane. (2016). A Framework For Marketing Management (6th ed.). Pearson Education.

Kumparan. (2019). Menilik Prosfek Fashion Muslim di Indonesia. Kumparan. https://kumparan.com/kumparanstyle/menilik-prospek-fashion-muslim-diindonesia

Lupiyoadi, R., \& Ikhsan, ridho bramulya. (2015). praktikum metode riset bisnis. penerbit salemba empat.

Mulianingsih, D., DH, A. F., \& Alfisyahr, R. (2019). Pengaruh Motivasi Belanja Hedonis Terhadap Kecenderungan Pembelian Impulsif di Online Shop (Survei Online pada Konsumen Zalora Indonesia di Kota Surabaya). Jurnal Administrasi Bisnis, 66(1), 56-66. 
Muthiah, I., Parawansa, D. A. ., \& Munir, A. R. (2018). Pengaruh Visual Merchandising, Display Product, Dan Store Atmosphere Terhadap Perilaku Impulse Buying ( Studi Kasus : Konsumen Matahari Departement Store Di Kota Makassar ). Hasanuddin Journal of Applied Business and Entrepreneurship, 1(2), 88-103.

Novia, J. (2015). The Effect of Visual Merchandising on Impulsive Buying with Impulsive Buying Tendency As Moderating Variable. Journal The Winners, 16(1), 1-5. https://doi.org/10.21512/tw.v16i1.1537

Pancaningrum, E. (2017). Visual Merchandising dan Atmosfer Toko: PengaruhnyaA Terhadap Keputusan pembelian. JIEP, 17(1), 23-40.

Sudarsono, J. G. (2017). Pengaruh Visual Merchandising Terhadap Impulse Buying Melalui Positive Emotion Pada Zara Surabaya. Jurnal Manajemen Pemasaran, 11(1), 16-25.

Sumeisey, G. M. (2014). The Effect of Visual Merchandising on consumer Impulse Buying Behavior. Jurnal EMBA, 2(3), 1413-1423.

Sunyoto, D. (2014). Praktik Riset Perilaku Konsumen (Teori, Kuesioner, Alat, dan Analisis Data). CAPS (Center of Academic Publishing Service).

Thomas, A., Louise, R., \& Vp, V. (2018). The Impact of Visual Merchandising, on Impulse Buying Behavior of Retail Customers. International Journal for Research in Applied Science \& Engineering Technology (IJRASET), 6(Ii), 474-491. 